\title{
Castles in the Air: Debunking the Space Settlement Prize
}

\author{
Thomas Gangale ${ }^{1}$ \\ OPS-Alaska, Petaluma, California, 94952
}

\begin{abstract}
Alan Wasser has proposed federal legislation that would have the United States recognize extraterrestrial claims to real property, based on a unilateral reinterpretation of the 1967 Outer Space Treaty. The Space Settlement Initiative appears on the National Space Society website, although the NSS has not endorsed it. Both the Artemis Society and the Moon Society have endorsed the initiative. The issue of private property rights in outer space has been one of high visibility in the American citizen pro-space movement for more than a quarter-century, and the issue has profound policy ramifications in both the near term (because the proposal is a current subject of debate) and long term (because, if enacted, it would a have dramatic effect on international space law and would shape the future commercial development of outer space).
\end{abstract}

What is the case for or against the current international legal regime? Has it indeed impeded space development? Are there certain claims of national sovereignty and private property that can be asserted under the present international law of outer space? If not, should changes be made to permit such claims? In what directions should the international law of outer space develop? The libertarian agenda to tear down the international legal regime of outer space is not only based on the erroneous premise that it presents a barrier to private enterprise, but that the success of this agenda would create legal uncertainty, thereby tending to discourage investment, as well as set the stage for armed conflict in outer space.

The Space Settlement Initiative turns international law on its head, as well as relying on a distorted rewriting of history, misunderstanding of legal principles, and a new adventure in voodoo economics.

\section{Eyes on the Prize in the Skies}

A lan Wasser, a former chairman of the Executive Committee of the National Space Society, proposes federal legislation that would have the United States recognize extraterrestrial claims to real property, based on a unilateral reinterpretation of the Outer Space Treaty. The Space Settlement Initiative appears on the NSS website, although the NSS has not endorsed it (Wasser 2004). Both the Artemis Society and the Moon Society have endorsed the initiative (Space Daily 2003). Wasser's scheme for huge land claims on the Moon and Mars goes back a long way, as does his antipathy for the Outer Space Treaty and his public statements distorting the history of that treaty and international law in general. His idea of extraterrestrial land claims found its way into print as early as 1988. By 1997, Wasser had drafted legislation (Wasser 1998). By 2004, he had formed the Space Settlement Institute, with himself as chairman, his son David as executive director, and Douglas O. Jobes as president. The mission of the institute is to lobby for the passage of the Space Settlement Prize Act (SSPA) into law.

It will take billions of dollars to develop safe, reliable, affordable transport between the Earth and the Moon. Neither Congress nor the taxpayers wants the government stuck with that expense. Private venture capital will support such expensive and risky research and development ONLY if success could mean a multi-billion dollar profit. Today, there is no profit potential in developing space transport, but we have the power to change that. We have the power to create a "pot of gold" on the Moon, waiting for whichever companies are the first to establish a "space line" and lunar settlement by risking their own necks, money and sweat.

How? By making it possible to claim and own -- and re-sell to those back home on Earth -- the product that has always rewarded those who paid for human expansion: land ownership.

\footnotetext{
${ }^{1}$ Executive Director, AIAA Professional Member.
} 
The proposed legislation would commit the U.S. to granting that recognition if those who establish the settlements meet specified conditions, such as offering to sell passage on their ships to anyone willing to pay a fair price.

The first settlement on the Moon should be able to claim up to 600,000 square miles. Getting to Mars will cost much more and Mars itself is larger than the Moon. Therefore the first Martian settlement should be able to claim up to $3,600,000$ square miles, roughly the size of the United States, worth 230 billion dollars at even $\$ 100$ per acre (Wasser 2001).

We should be trying to find a Congressional representative to introduce legislation saying that, while the U.S. makes no claim of national sovereignty, until and unless a new treaty on outer space property rights is adopted, all U.S. courts are to recognize and defend the validity of a land claim by any private company (or group of companies) which met the specified conditions (Wasser 1997).

It is rare for Congress to take the initiative in foreign policy; rather, it usually defers to the President. It is only in a case where the administration's foreign policy is in serious trouble in terms of domestic politics that Congress will react strongly enough to affect the policy. An example of this was the Congressional efforts to reverse the Reagan administration's "constructive engagement" policy toward the apartheid regime in South Africa (Treverton and Varle 1992). The issue of outer space property rights is hardly likely to rise to the level where thousands of people take to the streets to demand such a change in American foreign policy. Thus, Congress will do nothing. On the outside chance that Wasser were able to rope a member of Congress into introducing his bill, it would likely attract no cosponsors and would be referred to a subcommittee, never to be heard from again. In the unlikely event that Congress actually were to pass Wasser's bill, the President would summarily veto it; first of all because all administrations adamantly defend the executive branch's historical prerogative in foreign policy, and secondly because no administration would acquiesce in national legislation contrary to longstanding American foreign policy, since doing so would erode presidential authority over foreign policy, and finally, the State Department would vehemently oppose a bill that it regarded as being a treaty violation. By any calculation, "trying to find a Congressional representative to introduce" the SSPA is a fool's errand. This is simply not how the foreign policy apparatus of the United States works.

Since it would not cost anything, or need any appropriations, such legislation might pass as a minor revision of property law (Wasser 1997)....

What Wasser proposes is not "a minor revision of property law;" it is a major foreign policy initiative that reverses 40 years of unwavering American commitment to the Outer Space Treaty. Since that treaty is the bedrock of international space law, the cost of unilateral national legislation aimed at diluting the treaty would be incalculable in terms of destabilizing the entire framework of international space law. It can be assumed that many states would be hostile to such a unilateral act, and rather than "adopt similar laws," states would be far more disposed to enact national legislation repudiating all private property claims in outer space. Forcing an issue usually polarizes the situation. Far from promoting commercial space development by removing a supposed barrier, very real barriers would be thrown up. If anything, commercial space activity would be likely to contract in this atmosphere of political hostility and legal uncertainty. Positions on this issue would harden, and it might take decades for them to soften to the point where meaningful negotiations could take place. Rather than a space Renaissance, Wasser's proposal would plunge space development into a Dark Age.

One extreme would be a unilateral assertion of national authority. For example, the U.S. government could abrogate the Outer Space Treaty and declare sovereignty over some or all of the moon (while noting that the American flag is already there). Or, a bit more subtly, a government might extend recognition to certain property claims (probably those of its own citizens or companies) even without claiming sovereignty over the territories in question. Such unilateralism, however, would generate international tensions and, in all likelihood, competing claims by foreign governments. The rights of the supposed property owners - recognized by the courts of only one country - could hardly be said to exist (Silber 1998).

Oblivious to the danger, Wasser "would personally like to see" the United States withdraw from the Outer Space Treaty (Wasser 1997). On other occasions, however, he alleges that his scheme does not violate the treaty because it does not require the United States to exercise sovereignty.

\section{The Land Claim Recognition Analysis}

Jobes' and Wasser's (2004) “Land Claim Recognition (LCR) Analysis" is replete with misunderstood and misapplied points of law. Furthermore, they appear to have little knowledge of American government or of how its foreign policy apparatus operates:

The appropriate legal framework for land claims recognition in space is the "use and occupation" standard from civil law. Use and occupation means the claimants, by establishing a permanent presence on the land, have mixed their labor with the soil and created property rights that are independent of government.

In civil law countries like France, property rights have never been based on sovereignty as they have in the U.S. (which inherited the "common law" standard from the U.K.). Even in the U.S, derivatives of civil law are used by some states. From the New American Encyclopedia: 
Common law was generally adopted in the U.S., although Louisiana state law is based upon the Code Napoleon, and other states have partially codified systems. Civil law often relies on precedent, just as many common law rules are codified by statute [as in civil law] for convenience.

Use and occupation must be the standard for any land claims regimen in space, because the common law standard cannot be applied on a Moon where sovereignty itself is barred by international treaty. Congress will have to decree that, because there can be no government on the Moon, a permanent base or settlement can give itself title just as though it were a government (Jobes and Wasser 2004).

There are a number of problems with the above passages. First of all, the US is one of those countries whose legal system derives from common law, so how could it legitimately espouse a civil law theory of property rights in outer space? While it is true that Louisiana, as a former territory of France, has a legal tradition that descends from civil law, Louisiana law is not federal law, and what Jobes and Wasser aim at is the extraterritorialization of federal law to the Moon or Mars. In this context, Louisiana law, whatever its tradition may be, is irrelevant. So, if "use and occupation must be the standard for any land claims regimen in space, because the common law standard cannot be applied on a Moon where sovereignty itself is barred by international treaty," this puts Jobes and Wasser between a Moon rock and a hard place. Moreover, Congress cannot "decree" anything. It may pass bills, which if the President signs them, become law. As a common law nation, "because there can be no government on the Moon, [if a] permanent base or settlement [were to] give itself title just as though it were a government," it is hard to see how the United States could recognize any such title. The legal concept is incompatible with the legal system of the United States. On this basis alone, any US court is likely to shoot such legislation down in flames. Jobes and Wasser write as though the US legal system were under the complete and direct control of Congress. Have they not heard of the "separation of powers" principle?

Secondly, the civil law concept that mixing labor with the soil and creates property rights is inconsistent with Wasser's earlier suggestion that wealth could be created "out of thin vacuum (Wasser 1997)." But, understandably, they would like to have their green cheese cake and eat it too.

Finally, if "use and occupation means the claimants, by establishing a permanent presence on the land, have mixed their labor with the soil and created property rights that are independent of government," why is it necessary for any government to legislate in this matter? In the absence of government, the right exists by virtue of use and occupation, and the firepower to ensure the continuance of use and occupation. However, this implied use of force is a function of government. For "a permanent base or settlement [to] give itself title just as though it were a government," it would have to be a government. What is a government? In the present system of nation-states, a government is what the governments of other nation-states say it is. The legitimacy of any government depends in large part on its recognition by other governments. Thus, ultimately, for Jobes' and Wasser's ideas to have any specie in the nation-state system, the states of Earth would have to recognize lunar and Martian states. Such ideas may be vehicles for B-grade sci-fi film plots, but they do not have much thrust as a basis for public policy.

Participation by other space-faring nations would also help demonstrate these activities are in compliance with the "benefit of all mankind" requirement. Land claim recognition legislation could even direct the U.S. State Department to negotiate treaties requiring the private entities to form multinational consortia, to assure other nations that land claim recognition is not just an American attempt at a Lunar land grab (Jobes and Wasser 2004).

If the few launching states pig up all of the outer space goodies, that is not "for the benefit of all mankind," it is for the benefit of some favored few of mankind. Furthermore, pursuant to Article II, Section 2, Clause 2 of the Constitution of the United States, the President:

... shall have Power, by and with the Advice and Consent of the Senate, to make Treaties, provided two thirds of the Senators present concur....

The House of Representatives has no role at all in treaty-making, and the Senate has only the reactive role of giving its advice and consent, not a proactive role. Both houses have standing committees on foreign relations, but their purview is limited to the general legislative power of oversight and investigation. The Congress may direct the State Department all it wants, and the Secretary of State, being answerable only to the President, may nod politely and go about her business.

\section{Historical Issues}

Wasser has been playing fast and loose with history at least since 1988 :

President Johnson was said to be in earnest for such a resolution because of the uncomfortable situation which existed since the Soviet Union soft-landed the first spacecraft on the lunar surface_Luna 9 on 3 February 1966. Though the United States landed Surveyor 1 four months later on 2 June; as there was no precedent for appropriation of extraterrestrial territory, it was unknown what approach the Soviets might take, and how international law would eventually rule. 
Though this Treaty purports to endorse the development of the Moon and space in general, it contributes no fiscal or policy support to such developments. In fact, it places severe, probably prohibitive restraints, on such developments.

Wasser suggests that the opportunities and pace of space development would be greatly accelerated if the Articles were amended to say that, "Any nation, corporation or person that establishes a permanent manned settlement on the Moon or other celestial body, can claim all the land for 100 miles around (or 500, or 1000) (Space Daily 1988)."

In 1997, Wasser again points to the landing of Luna 9 as the triggering event for the Outer Space Treaty, and this time he also identifies the treaty as the triggering event for the collapse of the US space program:

On February 3rd, 1966, the Soviet Union's Luna 9 made mankind's first "soft" landing on the Moon. The U.S. was still trailing in the "space race" and wouldn't make its first soft landing for four more months.

To be able to divert more money to the escalating Viet Nam war, Lyndon Johnson had to send Arthur Goldberg to the Russians to negotiate a quick truce in the space race. The result was the 1967 Outer Space Treaty which, among other things, barred claims of "national sovereignty" in space.

The treaty doesn't actually bar private ownership of land beyond the Earth, but since national sovereignty has traditionally been the legal basis for private property rights in Anglo-Saxon law, the treaty is often assumed to have that effect.

I am convinced that that treaty provision is the real reason the space race ended, and space development has slowed to a crawl for the last quarter century. Significantly, space funding increased every year, in both the U.S. and U.S.S.R., until the passage of the 1967 treaty, and then decreased every year thereafter (Wasser 1997).

It is easy to account for Wasser's conviction that "that treaty provision is the real reason the space race ended." He is no scientist. If he were, he would understand that correlation is not necessarily evidence of cause and effect. The universe is replete with unrelated coincidences, and any effort to relate two events without scientific rigor leads to myth and superstition: my neighbor's cow was struck by lightning, therefore he must have angered and been punished by the gods. The real reason for the end of the space race was that the US so clearly won it. The space race was a venue of Cold War competition between the US and the USSR, an opportunity to show to the rest of the world whose technology was better, and once the point was made, in terms of national interest, there was no point in continuing to make the same point. To put it in language that any 10 -year-old can understand, the US went to the Moon on a double-dare. And, unsurprisingly, the US displayed an attention span comparable to a 10-year-old; we are a young country.

In saying, "No congress would ever have spent 100 Billion Dollars (in 1994 dollars) just for some nebulous 'prestige' benefit," Wasser only shows that he is unacquainted with Max Weber's three main dimensions of social life: wealth, power, and prestige. These are things that individuals and nation-states alike covet. Why did the US spend $\$ 500$ billion (2005 dollars) and 58 thousand lives on Vietnam? It certainly was not for fun or profit, so it must have been for power or prestige. For the US to have or to not have power over what Johnson called "a raggedy-ass little fourth-rate country" was relatively inconsequential; neither the American global strategic position, nor even the American strategic position in eastern Asia, was substantially weakened by the fall of the Indochinese dominoes. What really suffered throughout the 1970s as a result of the loss in Vietnam was American prestige. As it turned out, we could not "pay any price, bear any burden, meet any hardship, support any friend, oppose any foe, in order to assure the survival and the success of liberty (Kennedy 1961)," and bumping up against that bruising reality was a bitter blow to American pride. On the other hand, landing the first humans on the Moon was a sorely needed source of American prestige abroad, although it was a less-effective salve to the domestic American psyche.

Wasser asserts that Johnson wanted to "negotiate a quick truce in the space race" to "divert more money to the escalating Viet Nam war." As can be seen in Figure 1, canceling the US space program outright and giving all of NASA's budget to the Department of Defense would hardly have been noticed, either then or since. The historical fluctuations of defense spending dwarf the NASA budget.

Also, looking at only the funding history misses the programmatic details. The decline in the NASA budget starting in 1967 was due to the fact that the major capital investments in infrastructure (assembly facilities, test chambers, transportation systems, launch pads, et cetera) to support the Apollo program had been completed, as had most of the engineering design work for these ground support systems and flight systems. When one considers that from 1968 to 1972, the US flew 11 Apollo missions at a time when the NASA budget (which of course included funding for programs other than Apollo) averaged \$18 billion in 2005 dollars, compared to the peak budget in 1966 of $\$ 31.4$ billion in 2005 dollars, it becomes obvious that the US could have continued to explore the Moon indefinitely and relatively inexpensively. ${ }^{2}$ That the US did not do this had nothing at all to do with the Outer Space

\footnotetext{
${ }^{2}$ It should be noted that the 2005 NASA budget was $\$ 16$ billion, or about $90 \%$ of its average budget during the Moon mission years; yet this is considered a starvation budget that barely keeps the Space Shuttle and International Space Station alive.
} 


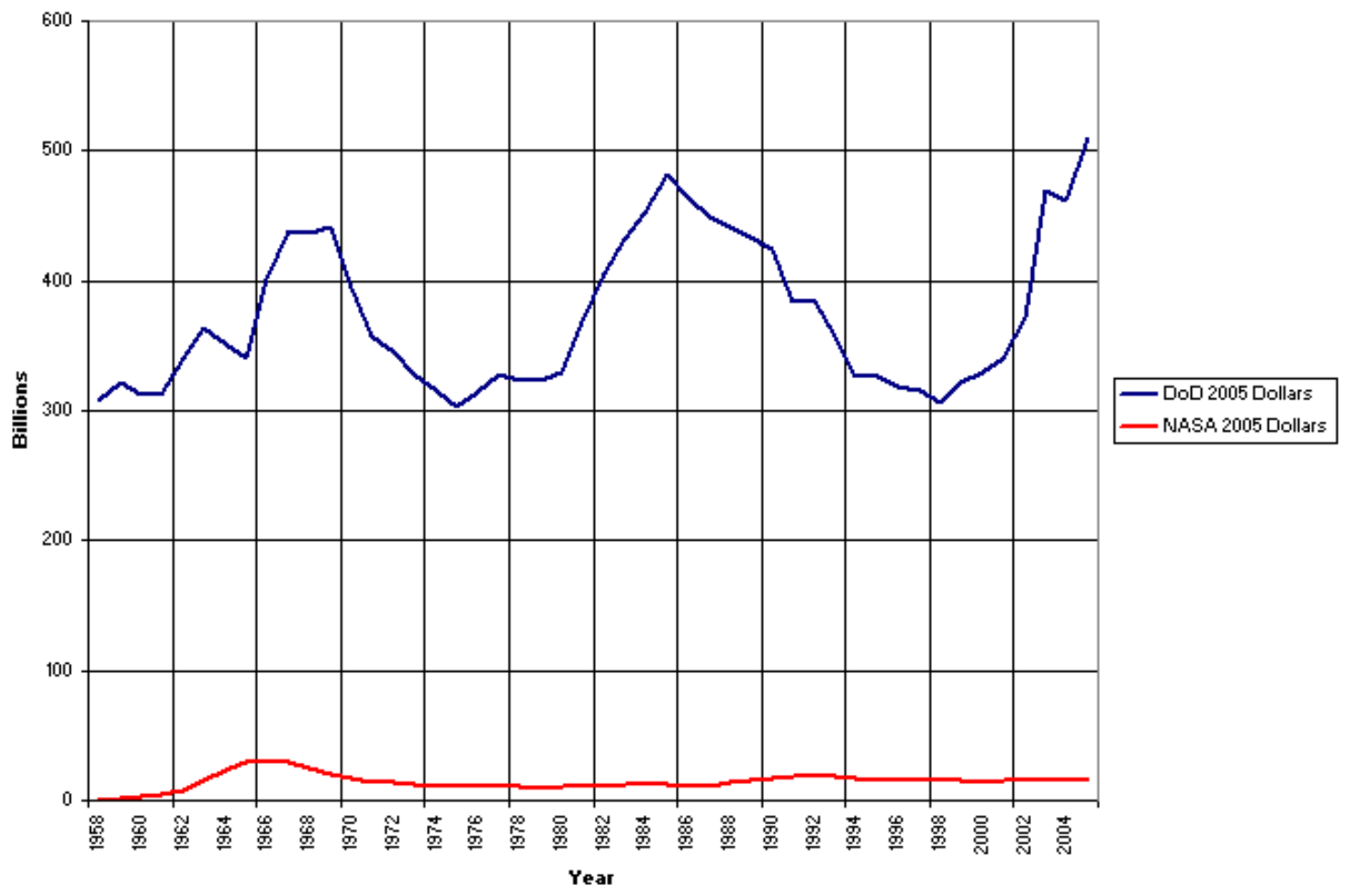

Figure 1. NASA and DoD Budgets, 1958-2005

Sources: sae.org, en.wikipedia.org/wiki/NASA_Budget

treaty, and very little to do with the Vietnam War. The programmatic decisions affecting the lunar exploration program, specifically the cancellation of the last three Apollo missions, came in 1970, three years after ratification of the Outer Space Treaty, during the time when the American involvement in Vietnam was winding down. Harrison Schmitt refers to other programmatic decisions in 1972:

In 1969 and 1970 there was a tremendous amount of other plans. We were working on all sorts of things.

The momentum seemed to be for the United States to move forward with a continuous lunar exploration program and implicit in that is the potential exploitation of resources on the Moon in the foreseeable future, whereas in 1972 that all changed. The Nixon administration cancelled all those activities and it became obvious to the world that we would not do that (USS 1980, 54).

In short, the US went to the great expense of building a railroad to the Moon which could have operated for many years and eventually supported profit-making enterprises, but instead it chose to tear up the tracks and scrap the rolling stock. But, this was a political decision, unrelated to treaties and wars. At best, Nixon was ambivalent about continuing the exploration of the Moon; to some extent, it served to bolster America's global prestige, but it also served to keep the Kennedy mystique alive.

One argument that Wasser uses to support his case against the current treaty regime is that in the 1960s the US was concerned that the USSR would land humans on the Moon first and would use this to establish a claim to the Moon; thus, in essence, the US was allegedly frightened into the position of championing the concept of outer space as a commons and into signing a bad treaty. Supposedly, following the landing of the Soviet robotic spacecraft Luna 9 on 3 February 1966 :

Newspapers ran serious articles about whether the Russians would use their landing to claim ownership of the Moon. Government officials worried about the supposedly overwhelming military advantage the U.S.S.R. would gain by seizing the "ultimate high ground." Reassuringly, the articles concluded that under traditional international law, no one could really claim the Moon until they had at least made a manned landing!

Those articles are an excellent reminder that fear of a Russian victory in the race to the Moon, leading to a Russian claim to the Moon, was a major reason Congress kept increasing the funding for Apollo. No congress would ever have spent 100 Billion Dollars (in 1994 dollars) just for some nebulous "prestige" benefit (Wasser 1997). 
There is a great deal of distortion here. First of all, if indeed some "newspapers ran serious articles about whether the Russians would use their landing to claim ownership of the Moon," they were seriously misinformed:

Debate about whether to use air or high seas analogies ended in 1961, when the Soviet government accepted General Assembly Resolution 1721A. It expressed preliminary agreement on two key propositions:

(a) International law, including the Charter of the United Nations, applies to outer space and celestial bodies.

(b) Outer space and celestial bodies are free for exploration and use by all States in conformity with international law and are not subject to national appropriation (Peterson 1997).

Furthermore, in its Draft Declaration of the Basic Principles Governing the Activities of States Pertaining to the Exploration and Use of Outer Space, which the Soviet Union submitted to COPUOS on 10 September 1962, it declared in Principle 2:

Outer space and celestial bodies are free for exploration and use by all States; no State may claim sovereignty over outer space and celestial bodies (COPOUS 1962).

At the time, the Soviet Union had flown four manned missions in Earth orbit, longest 3 days, 22 hours, 22 minutes (Vostok 3); the United States had flown only two orbital missions, the longest 4 hours, 56 minutes (Mercury-Atlas 7). Soviet crews had accumulated 7 days in space; American crews only 10 hours. The Soviet Union had impacted Luna 2 on the lunar surface, and had photographed the never-before-seen far side with Luna 3. By any quantitative or qualitative measure, the Soviet Union was winning the "space race." Yet, the Soviet Union had taken the position that "no State may claim sovereignty over outer space and celestial bodies."

So whatever some newspapers might have been publishing, the Johnson administration and the Congress knew full well that the USSR had committed itself to the freedom of outer space five years earlier. In fact, no extant principle of international law would have prevented the Soviet Union from claiming the Moon in 1959 when Luna 2, carrying a number of medallions with the national coat of arms, impacted the Moon. "The Soviet Union would have had the right to claim vast areas of outer space as its own territory, including part or even all of the Moon, based on historical precedents of exploration and conquest (Tennen 2003)...." The USSR made no sovereignty claims on the Moon when it impacted Luna 2 in 1959, nor when it landed Luna 9 in 1966, nor was there any apprehension that it would do so were it the land the first crew on the Moon.

Wasser is also misleading when he makes it sound as though Arthur Goldberg rushed off to Moscow to cut a hasty deal. Quite the contrary, the Outer Space Treaty was the culmination of years of groundwork, having as its progenitors UN GA Resolution 1721 (XVI) in 1961 and Resolution 1962 (XVIII) in 1963. These resolutions, as well as less-prominent ones of the early space age with similar titles, "were without exception the outcome of prolonged preliminary political negotiations and compromises between the two space powers (Csabafi 1965)." It is also true that they were without exception adopted without vote, and that "[t]he operative parts of the resolutions 1721 and 1962 clearly show the crystallization on the legal principles (Csabafi 1965)" of outer space years before Ambassador Goldberg allegedly ran off "to the Russians to negotiate a quick truce in the space race (Wasser 1997)." Resolution 1962 provided "the international community with norms, in respect of which, the Member States of the United Nations, including the space Powers, have achieved consensus (Csabafi 1965)." The correct reading of history is that the 1967 Outer Space Treaty was the extension of that consensus and the elaboration of those principles, not the result of some hasty, last-minute scramble.

Finally, rather than the United States having been anxious to conclude an early treaty:

The Soviet Union, supported by Socialist Countries and at first by some other States too, was in favour of a treatydeclaration. The United States, on the other hand, wanted a General Assembly resolution (resolution-declaration) and not a treaty. The Soviet argument [was] partly based on the relevant provision of the UN Charter according to which resolutions of the General Assembly are without legal binding force, and partly on the suggestion, that the agreed principles of space law should be incorporated in a legally binding instrument (treaty) (Csabafi 1965).

From this we see that, both counterintuitively and counter to Wasser's assertions, at the time of its greatest technological lead over the United States, the Soviet Union was anxious to establish an air-tight legal system for outer space, whereas the United States desired more flexibility. However, this was a difference over the form of the agreement, not over the principles themselves. The fact is that the US desired outer space to be internationally recognized as a commons beginning in the early 1950s, long before it became apparent that the USSR had an initial advantage in space launch capability. Thus, to say that the US would have preferred a treaty that allowed the appropriation of space is an inaccurate reading of the historical record, and this false assertion cannot be used to advance the idea that the US should reverse its position after 50 years, or to subvert, violate, or withdraw from the Outer Space Treaty.

Another historical point to be made is that John F. Kennedy's May 1961 commitment to "achieving the goal, before this decade is out, of landing a man on the Moon" was deliberately chosen as the most spectacular goal in human spaceflight that the US could be most confident in accomplishing ahead of the USSR. In other words, it was clearly beyond the near-term capabilities of either country, and the US would have plenty of time to catch up to the 
USSR and to surpass it. The US did exactly that. At the midpoint of the Gemini program at the end of 1965, as work continued on the Outer Space Treaty, the US held every important advantage over the USSR on the road to a human landing on the Moon: heavy-lift launch capability (Saturn 1 and Saturn 1B), fuel cell technology to power longduration missions (Gemini 4), mission duration sufficient to reach the Moon and return to Earth (8 days on Gemini 5, surpassed by 14 days on Gemini 7), rendezvous of two manned spacecraft (Gemini 6 and Gemini 7), and extravehicular activity (EVA, Gemini 4). In contrast, at that point the USSR had only demonstrated battery power of insufficient duration for a lunar mission (5 days on Vostok 5), no rendezvous capability, and it never man-rated its Proton launch vehicle. When the Outer Space Treaty was opened for signing on 27 January 1967, the Gemini program had completed six manned rendezvous and docking missions with numerous EVAs, and the launch of the first Apollo mission was expected to occur within weeks. ${ }^{3}$

\section{Theoretical Issues}

Wasser's idea of bestowing nation-sized land grants to corporations is without theoretical grounding. Locke expressed the labor theory of property ownership:

It is labour then which puts the greatest part of value upon land, without which it would scarcely be worth any thing: it is to that we owe the greatest part of all its useful products; for all that the straw, bran, bread, of that acre of wheat, is more worth than the product of an acre of as good land, which lies waste, is all the effect of labour: for it is not barely the plough-man's pains, the reaper's and thresher's toil, and the baker's sweat, is to be counted into the bread we eat; the labour of those who broke the oxen, who digged and wrought the iron and stones, who felled and framed the timber employed about the plough, mill, oven, or any other utensils, which are a vast number, requisite to this corn, from its being feed to be sown to its being made bread, must all be charged on the account of labour, and received as an effect of that: nature and the earth furnished only the almost worthless materials, as in themselves. It would be a strange catalogue of things, that industry provided and made use of, about every loaf of bread, before it came to our use, if we could trace them; iron, wood, leather, bark, timber, stone, bricks, coals, lime, cloth, dying drugs, pitch, tar, masts, ropes, and all the materials made use of in the ship, that brought any of the commodities made use of by any of the workmen, to any part of the work; all which it would be almost impossible, at least too long, to reckon up (Locke 1689, 43).

By this theory, the Moon has no present value because no one is presently working the land. More important, however, is the principle by which common property becomes private property: the land must be worked.

But, what counts as sufficient labour? Extremes are clear (spitting in an ocean is insufficient to count as labour, for example, and fully cultivating an unowned piece of land is obviously sufficient). Is it sufficient to expend labour in the first place, or must the labour be of a certain type?

Having raised these doubts, though, we can see that one limit to property ownership appears to be the capacity to work the land, i.e., if I can't labour this land, I can't have it.

[There is also t] he spoilage limitation: I am not entitled to take land from the commons if it will spoil or go to waste. If the products of labour spoil, I have taken more than my share. I am required remember to improve the land; in allowing land to go to waste or to spoil, I am not improving the common stock (University of Bristol 2005).

Quite simply, in pushing for continent-sized land grants, Wasser has no understanding of these philosophical issues:

In countries like France, which follow what is called "civil law" (as opposed to "common law" which the U.S. inherited from the U.K.) property rights have never been based on territorial sovereignty but on the "Natural Law" theory that individuals mix their labor with the soil and create property rights independent of government, which merely recognizes those rights (Wasser 2001).

If we accept the natural law concept that labor with the soil creates property rights, a small settlement on the Moon would create property rights for itself in its vicinity, rights to the land that is uses and occupies. Logically, this argument cannot extend property rights to claims the size of Alaska or the United States.

Some critics object that would allow a settlement to claim more land than it can use, but the amount of land that can be used depends on what you are using it for. Nineteenth century land grant farmers used 40 acres and a mule. Modern mechanized farms use vastly more land than that. Cattle ranchers use much more land than farmers. But none of those are the size criteria that should be used for a Lunar settlement because, of course, the settlement will not make its living by either farming or ranching.

The plan is to let settlements recoup the cost of getting there in the first place by selling land. If you are in the real estate business, especially if you are selling totally raw Lunar land, you can use all the acreage you can get title to (Wasser 2001).

This reasoning is utterly preposterous. Speculating in a commodity does not equate to using a commodity for a productive purpose. If Wasser cornered the world market in pork bellies and beef, this would be less productive than cooking and serving a single bacon burger. The latter activity creates added value, whereas speculation is simply

\footnotetext{
${ }^{3}$ Ironically, the crew of Apollo 1 died that evening when a fire swept through their spacecraft.
} 
gaming the system to extract existing value from it, often to the detriment of someone else, as with Enron's gaming of the energy market to create artificial scarcities and price spikes in California in 2000-2001.

No person (either natural or juridical), simply by virtue of establishing regular transportation between the Earth and the Moon, would instantaneously acquire the capacity to improve a surface area the size of Alaska; therefore, it could not immediately appropriate so vast a territory from the commons (even were there a sovereign to recognize such a title). Furthermore, there can be no presumption that the entity could acquire sufficient capacity to work the land before the period terminated during which it had the sole capacity to operate a translunar transportation system. This gives rise to the possibility that, were the entity to have title to this extensive area, this would deny use to others who later acquired the capacity to work claimed but still-unused land. This would constitute a taking of land from the commons and letting it go to waste. Obviously, the idea of a land grant on Mars the size of the United States also fails these tests. Rousseau reduces Wasser's position to absurdity:

In general, to establish the right of the first occupier over a plot of ground, the following conditions are necessary: first, the land must not yet be inhabited; secondly, a man must occupy only the amount he needs for his subsistence; and, in the third place, possession must be taken, not by an empty ceremony, but by labour and cultivation, the only sign of proprietorship that should be respected by others, in default of a legal title.

In granting the right of first occupancy to necessity and labour, are we not really stretching it as far as it can go? Is it possible to leave such a right unlimited? Is it to be enough to set foot on a plot of common ground, in order to be able to call yourself at once the master of it? Is it to be enough that a man has the strength to expel others for a moment, in order to establish his right to prevent them from ever returning? How can a man or a people seize an immense territory and keep it from the rest of the world except by a punishable usurpation, since all others are being robbed, by such an act, of the place of habitation and the means of subsistence which nature gave them in common? When Nuñez Balboa, standing on the sea-shore, took possession of the South Seas and the whole of South America in the name of the crown of Castile, was that enough to dispossess all their actual inhabitants, and to shut out from them all the princes of the world? On such a showing, these ceremonies are idly multiplied, and the Catholic King need only take possession all at once, from his apartment, of the whole universe, merely making a subsequent reservation about what was already in the possession of other princes (Rousseau 1762, I 9).

Thus, although Wasser is not as audacious as Dennis Hope ${ }^{4}$ in claiming the whole universe from his apartment, it is a short journey from one position to the other, both of which are constructed on the same philosophical quicksand.

\section{Legal Issues}

In a number of Wasser's statements, he appears confused about what he is advocating:

I believe that, for claiming ownership over space real estate, some form of the classic Roman legal principal called pedis possessio will have to apply. Pedis possessio means that the first entity to set foot (pedis) upon and occupy a space can claim possession, and most of the world's property rights laws are based on that principal (Wasser 2004a).

What Wasser apparently does not understand is that the pedis possessio principle applies to res nullius; one may take possession of that which belongs to no one by setting foot upon it. However, the body of international law has clearly established that outer space and celestial bodies are res communis; as such, they are owned by the human community, and no one may take exclusive possession.

Article I of the Outer Space Treaty provides that "there shall be free access to all areas of celestial bodies." How is "free access" compatible with Alaska-size and even US-size land grants? Any meaningful property rights include the exclusive use of the owned land, negating "free access." Wayne N. White (1998) observes:

[One] reason for prohibiting territorial sovereignty was to ensure free access to outer space. If nations begin claiming large areas of outer space or on celestial bodies, it will prevent entities from other nations from having free access to both claimed and unclaimed areas of outer space.

Obviously, private appropriation on the scale of national territory would prevent free access as effectively as direct national appropriation.

Another problem with Wasser's concept surrounds the concept of "recognizing land claims:"

Under a land claim recognition protocol, Congress could pass legislation providing that for any private, non-government corporation or consortium that financed and built a space transportation system and permanent Moon base, a limited (but still very large) claim to lunar land around the base would be legally "recognized" by the U.S. government.

Recognition means the government would acquiesce to, or decide not to contest, the claim, but not assume any sovereignty over it. Once the space transportation system and lunar base were certified, the private consortium would be

\footnotetext{
${ }^{4}$ Dennis Hope began selling "property" on the Moon in 1980 at \$20 per acre, and claims to have had nearly 3.5 million customers, including two former US presidents. He also claims every other celestial body in the solar system with the exception of the Earth and the sun.
} 
free to immediately mortgage or sell, back here at home, some of their lunar land deeds to recoup their investment and make a profit (Wasser 2004a).

What would be the credibility of this so-called "recognition?" Would such a law obligate to US to take action against those who did not "recognize" or otherwise violated a supposed property right? If so, such action would be an act of sovereignty. Before getting into the enforcement issue, let's tackle a more basic one. The fact that only states are parties to international agreements cannot be construed to mean that they have no bearing on nongovernmental entities. States bear international responsibility for the activities of nongovernmental entities under their jurisdiction. A state cannot license nongovernmental activities that are prohibited to the state. For example, the US cannot get around the 1963 Test Ban Treaty by licensing a contractor such as Halliburton to detonate a nuclear device above ground. If states were to recognize a real property claim by a nongovernmental entity under its jurisdiction, this would constitute national appropriation by "other means," in violation of Article II of the Outer Space Treaty.

It has been suggested that states could unilaterally establish a domestic registry for the purpose of documenting the claims of their nationals to space resources, purportedly consistent with the non-appropriation principle. This "consistency" is provided by the artifice of proclaiming this registration scheme "not to be appropriation." For example, one group of proponents asserted that "[i]n doing so, the nation could make it clear that it was not claiming sovereignty over such resources, but simply recognizing the claims of its citizens (emphasis added)." This is a distinction without a difference.

Recognition of claims is only one side of the equation. The other side is the exclusion or rejection of any competing or conflicting claims. The application of this de facto exclusion of other states and their nationals by its very nature would constitute a form of national appropriation. Thus, state recognition of claims to extraterrestrial property by its nationals is national appropriation "by any other means" prohibited by article II, no matter what euphemistic label is employed to mask the obvious (Tennen 2003).

With regard to enforcement, yes indeed, Wasser intends to obligate acts of sovereignty:

The law could pledge to defend extraterrestrial properties by imposing sanctions against aggressors (Wasser 1997).

It cannot be denied that imposing sanctions is an act of state. To defend extraterrestrial properties via this mechanism would therefore serve to support national appropriation by other means, in violation of Article II of the Outer Space Treaty. Furthermore, since such sanctions would have no legitimacy in international law, they would violate other international obligations. For example, suppose that an American company established a permanent settlement on the Moon and claimed land according to the SSPA formula, and suppose a foreign company later established a value-extractive operation 100 kilometers from the American settlement, within its land claim. This would in no way violate international law, yet would violate the SSPA, and could trigger the imposition of sanctions. The US could impose the sanctions either against the foreign company directly, against the state in which the foreign company were based, or both. In any case, the foreign state, either on its own behalf or on behalf of the sanctioned company, would be well within its rights to bring a complaint against the US before the World Trade Organization (WTO). There would be no shred of international law with which the US could defend itself against such a complaint, and the WTO dispute settlement system would unquestionably find for the plaintiff. WTO member states are committed to having their national laws and regulations reviewed by the WTO. If the WTO rules against a state, it must abolish the law, or pay a fine to the plaintiff country. If the state in violation does neither, the plaintiff country is empowered to enact trade sanctions against the offending country. In extreme cases, the WTO can encourage systemic sanctions against the offending country. American companies that do international business are very aware of the power of the WTO, and it would be quite obvious to them that the threat of sanctions contained in the SSPA has no credibility. Thus, passage of the SSPA would not incentivize the commercial development of celestial bodies.

The major policy statements and legal provisions of the Space Settlement Prize Act are contained in Sections 2 and 4. A number of paragraphs are merely declaratory, some of which are benign and are omitted from the following analysis, while others are contrary to international law. On the other hand, its legal provisions, in every instance, rest on the misinterpretation of existing law.

Section 2, paragraph 3 of the SSPA states:

Space exploration and settlement with private financing will produce new tax revenues for the United States.

This is almost certainly untrue in the short term. Among the arguments raised against the Moon Agreement was the prospect of an international regime that would levy such a heavy tax burden on commercial operations as to render them unprofitable. Since commercial operations involving human spaceflight are likely to remain only marginally profitable for quite some time once they do reach profitability, it is extremely doubtful that Congress would care discourage the development of a nascent industry by imposing any tax liability whatsoever. We see here how space property rights advocates talk out of both sides of their mouths; taxation by an international regime would squash the private development of space, but the private development of space would "produce new tax 
revenues for the United States." Well, let's get the story straight and stick to it... are private developers going to be able to pay their taxes or not?

Section 2, paragraph 4 of the SSPA states:

A new, additional, incentive is needed because the potential short-term profit sources are currently much too small to attract the billions of dollars of private capital necessary.

Ah, so here we have the answer to the question just posed. The profit margin will be so small that, not only will developers be unable to pay taxes, they will need some sort of corporate welfare "incentive."

Section 2, paragraph 5 of the SSPA states:

The potential value of land on the Moon, Mars, or an asteroid can provide an additional economic incentive for privately funded space settlement at no cost to the government.

Ah, that magic word... potential! The Moon and Mars have no present value, since the means to go there, to work their lands, and to extract value from them, do not exist. At the present time, they are so much dust. But, of course, they have potential. In Section VI, "Financial Issues," we will explore Wasser's calculations of "potential value."

Section 2, paragraph 6 of the SSPA states:

Prizes such as the Orteig Prize and the Ansari X Prize have an excellent record of promoting privately funded innovation, so Congress wishes to establish a "Space Settlement Prize" to promote the human settlement of the Moon and Mars.

Burt Rutan's Scaled Composites spent \$25 million on the SpaceShipOne project to win the \$10 million Ansari X Prize, a loss of $\$ 15$ million. Of course, Microsoft cofounder Paul Allen, whose estimated net worth is $\$ 21$ billion provided the venture capital, and what is $\$ 25$ million to him (Wired.com 2004)? Money was no object; the prestige of being first was the object. But then, Wasser does not believe in the allure of prestige.

Section 2, paragraph 7 of the SSPA states:

At some time in the future Congress may be in a position to add an appropriately large monetary award, but, for now at least, the tremendous economic value of land claims recognition should be more than sufficient.

Hold onto your wallets, Mr. and Ms. Taxpayer. Some day the space privateers will no longer be satisfied to joyride on Paul Allen's largess. That's peanuts compared to the billions they can loot from you. And, they will have to because, as we shall see later, there is no "tremendous economic value of land claims recognition."

Section 2, paragraph 8 of the SSPA states:

There is currently no international law on private land ownership in space, because most major nations have deliberately refused to ratify "The Agreement Governing the Activities of States on the Moon and Other Celestial Bodies, 1979, (hereafter called the "Moon Treaty"). The U.S. Senate's refusal to ratify means that the Moon Treaty's provisions are not "the law of the land" in U.S. courts, and therefore do not inhibit the actions of U.S. citizens or legislators.

In fact, there is currently "international law on private land ownership in space." It is flat out prohibited. Article II of the Outer Space Treaty states:

Outer space, including the moon and other celestial bodies, is not subject to national appropriation by claim of sovereignty, by means of use or occupation, or by any other means.

A property right cannot exist in the absence of a controlling legal regime. There is no legal system outside of sovereignty except that which is established between sovereigns, i.e. international law. In the absence of a legal system, obviously there can be no legal title to anything. The Outer Space Treaty does recognize some forms of ownership. Article VIII provides:

Ownership of objects launched into outer space, including objects landed or constructed on a celestial body, and of their component parts, is not affected by their presence in outer space or on a celestial body or by their return to the Earth.

How is such ownership possible if there is no sovereignty in outer space? In fact, there is sovereignty in outer space, not over territory, but over "space objects." Article VIII also provides:

A State Party to the Treaty on whose registry an object launched into outer space is carried shall retain jurisdiction and control over such object, and over any personnel thereof, while in outer space or on a celestial body.

On the other hand, the Outer Space Treaty does not provide for the ownership of land. If it did so, it would first need to recognize the establishment of sovereignty over territory that would be required to create the legal regime that would recognize the property right. But "national appropriation by claim of sovereignty" is expressly prohibited in Article II, so the property right over territory cannot exist.

Section 2, paragraph 9 of the SSPA states:

More importantly, the framers of the Moon Treaty found it necessary to attempt to write a rule forbidding private ownership of land on the Moon, clearly confirming that such an objective had not already been accomplished by "The Treaty on Principles Governing the Activities of States in the Exploration and Use of Outer Space, Including the Moon and Other Celestial Bodies", 1967, (hereafter known as the "Outer Space Treaty"), nor by U.N. resolution GA/res/1962. 
This statement is untrue on several points. First of all, as is made clear in the following statement before the Senate Subcommittee on Science, Technology, and Space by Art Morrissey, senior policy analyst for the White House Office of Science and Technology Policy:

The Moon Treaty is based to a considerable extent on the 1967 Outer Space Treaty. Indeed, the discussion in Outer Space Committee confirmed the understanding that the Moon Treaty in no way limits the provisions of 1967 Outer Space Treaty (USS 1980, 29).

Secondly, Wasser selects a single fact to support his erroneous conclusion and ignores the rest of the evidence. $\mathrm{He}$ fails to take note of the repetition and elaboration of principles not only from the Outer Space Treaty to the Moon Agreement, but from earlier from the International Cooperation Resolution, to The Declaration of Legal Principles, to the Outer Space Treaty. He asserts that a provision in a later document confirms that "such an objective had not already been accomplished" in an earlier document. It does no such thing. It is merely a restatement. Wasser misconstrues the purpose of repeating general provisions from one document to another, which is to provide continuity as well as to preclude fragmentation of the legal regime in cases where a state is party to one treaty and not another:

To some extent, the trend toward fragmentation is limited by the fact that new space treaties generally repeat the general provisions which have already been endorsed by earlier treaties dealing with outer space. Although this legislative technique may raise difficult questions about the relationship between the obligations created by different instruments, it enables law-makers to establish a legal system in which some basic rules are adopted by states which may not be bound by similar provisions in earlier treaties. As a result, the rules of space law acquire broader community support (Danilenko 1989).

Section 2, paragraph 10 of the SSPA states:

The ratification failure of the Moon Treaty means there is no legal prohibition in force against private ownership of land on the Moon, Mars, etc., as long as the ownership is not derived from a claim of national appropriation or sovereignty (which is prohibited by the Outer Space Treaty).

The failure of the Moon Agreement to be ratified by more than a handful of states, non-launching states at that, leaves the Outer Space Treaty as the source of the "legal prohibition in force against private ownership of land on the Moon, Mars, etc." This paragraph implies that a legal title of ownership could arise outside of sovereignty, but does not explain how.

Section 2, paragraph 11 of the SSPA states:

Presumably it is only a matter of time until new treaties are negotiated, establishing a functional private property regime and granting suitable land ownership incentives for privately funded space settlements. The U.S. will, of course, abide by such new international law when it has ratified such a new treaty. But, given the urgent need for privately funded human expansion into space, as soon as possible, something must be done immediately, on a provisional basis, to correct the present inefficiencies in the international standard on property rights in space and to promote privately funded space exploration and settlement.

In fact, functional property rights do exist under international law. The key word here is "functional." For a property right to exist, something or someone must be performing some value-extractive function on the land. The idea of granting continent-sized land titles to corporations has no relevance to this principle whatsoever. Since no entity has the capacity to perform value-extractive functions on all of a continental land-mass simultaneously, the theory of functional property rights cannot be used to advance continent-sized land claims. This paragraph also asserts that there are "present inefficiencies in the international standard on property rights in space." What are they exactly?

Section 2, paragraph 12 of the SSPA states:

For property rights on the Moon, Mars, etc., the U.S. will have to recognize natural law's "use and occupation" standard, rather than the common law standard of "gift of the sovereign", because sovereignty itself is barred by existing international treaty.

Natural law is a legal theory, not a legal system. Theoretically, natural law exists independent of recognition by a sovereign, so the proposition that the US "will have to recognize natural law" is doubletalk. Any law that the US "recognizes" by act of Congress is by definition incorporated into the system of sovereign law, irrespective of its origin in natural law theory. However, act of Congress recognizing property rights on the Moon or Mars would also be by definition an act of sovereignty, "sovereignty itself is barred by existing international treaty."

Section 2, paragraph 13 of the SSPA states:

U.S. courts already recognize, certify, and defend private ownership and sale of land which is not subject to U.S. national appropriation or sovereignty, such as a U.S. citizen's ownership (and right to sell to another U.S. citizen, both of whom are within the U.S.) a deed to land which is actually located in another nation. U.S. issuance of a document of recognition of a settlement's claim to land on the Moon, Mars, etc., can be done on a basis analogous to that situation.

It is true that the US legal system may have jurisdiction over certain cases in which the property in question is located in another nation, but the dispute over the property involves a US citizen. However, the US court finds its 
jurisdiction according to international law, not in violation of it. What is not in question in such cases is that there is a property that is subject to ownership by some entity under the sovereignty of some nation. On the other hand, the SSPA seeks to create a property right where none currently exists, in violation of international law; thus the SSPA's reference to these terrestrial cases is completely irrelevant.

Section 2, paragraph 14 of the SSPA states:

This legislation concerns only the issuance of such a U.S. recognition and acceptance of a settlement's claim of private land ownership based on use and occupation, regardless of the nationality of the owner, and nothing in it is to be considered a claim of national appropriation of, nor sovereignty over, any outer space body, or any part thereof.

As has been previously discussed, the assertion that the "settlement's claim of private land ownership [is] based on use and occupation" of millions of square kilometers is a fallacy. Wasser incorrectly equates buying and selling with use and occupation. Secondly, merely asserting that nothing in his proposed legislation "is to be considered a claim of national appropriation of, nor sovereignty over, any outer space body" does not make it true. If the character of an act depended only on its characterization by the actor, no crime could be prosecuted. It is analogous to asserting, "I will kill you, but nothing I do is to be considered an act of murder." Tell that one to the judge.

Section 2, paragraph 15 of the SSPA states:

The U.S. does not claim the right to "confer" private land ownership, and the U.S. states it is most definitely not making any claim of "national appropriation by claim of sovereignty, by means of use or occupation, or any other means" as prohibited by the Outer Space Treaty.

So, by this proposed legislation the US makes no claims; it simply arrogates the right to commit acts while not claiming to commit them.

Section 4, paragraph 1 of the SSPA states:

All U.S. courts and agencies shall immediately give recognition, certification, and full legal support to land ownership claims based on use and occupation, of up to the size specified in Sections 6.1, 6.2, and 6.3 below, for any private entity which has, in fact, established a permanently inhabited settlement on the Moon, Mars, or an asteroid, with regular transportation between the settlement and the Earth open to any paying passenger.

To "give recognition, certification, and full legal support to land ownership claims" is an act of sovereignty for the purpose of appropriation, which is prohibited by Article II of the Outer Space Treaty.

Section 4, paragraph 2 of the SSPA states:

For a land claim to receive such recognition and certification, the settlement must be permanently and continuously inhabited. The location and the population of the settlement may change, as long as there continues to be an inhabited settlement within the original claim.

The conditions for recognizing the claim are irrelevant, since the claim itself has no basis in international law, and recognition under any condition is a violation of international law.

Section 4, paragraph 3 of the SSPA states:

Deliberate abandonment of the settlement shall be grounds for invalidating land ownership recognition derived from that settlement, but there shall be no penalty for brief unintentional absences caused by accident, emergency, or aggression.

This paragraph is superfluous, since any land ownership recognition is invalid in the first place.

Section 4, paragraph 4 of the SSPA states:

Recognized ownership of land under this law shall include all rights normally associated with land ownership, including but not limited to the exclusive right to subdivide the property and sell portions to others, to mine any minerals or utilize any resources on or under the land, as long as it is done in a responsible manner which does not cause unreasonable harm to the environment or other people.

The US cannot guarantee rights where it has no legal jurisdiction. Where it exercises legal jurisdiction, it exercises sovereignty. To do so over lunar or Martian land area would be an act of sovereignty for the purpose of appropriation, which is prohibited by Article II of the Outer Space Treaty.

Section 4, paragraph 5 of the SSPA states:

If the requirements of this law continue to be met, all rights, privileges, and responsibilities shall be immediately transferable by sale, lease, or other appropriate means to any other private entity.

No rights can be transferable because no rights exist in the first place.

Section 4, paragraph 6 of the SSPA states:

As long as the required conditions continue to be met, U.S. recognition documents shall remain valid for 100 years or until the U.S. ratifies a treaty that establishes an international property rights regime which gives comparable reward to privately funded settlement, whichever comes sooner.

Any US recognition documents shall become invalid before the ink is dry.

Section 4, paragraph 7 of the SSPA states:

The U.S. pledges to defend recognized extraterrestrial properties by imposing appropriate sanctions against aggressors, whether public or private. It pledges never to allow the sale to U.S. citizens of any extra terrestrial land which was seized by aggression. But it makes no pledge of military defense of recognized extraterrestrial properties. 
The US has imposed appropriate sanctions against Cuba for half a century and has adhered to them with high fidelity, yet it is Fidel who holds the long-playing record. It is this paragraph in particular that exposes the SSPA for the farce that it is. Here on Earth, if someone runs you off your property, you call the law enforcement authorities. But on Mars, if someone runs you off your property, you call the US Secretary of State in the hope that she will testify before the House Committee on International Relations and the Senate Committee on Foreign Relations in support of passing sanctions legislation of dubious effectiveness. Ultimately, a right must be supported by a credible enforcement mechanism if it is to have any meaning. Since the SSPA eschews "military defense of recognized extraterrestrial properties," the rights that it purports to create are a tissue of illusions.

\section{Financial Issues}

Let us for the moment put aside Wasser's distortion of history, his disinterest in legal theory, and his disregard for international law, and examine the economic rational for his scheme.

So the "right" size for a claim is that size which is just large enough to justify the cost of developing reliable space transport and establishing a settlement, ... but small enough to force the development of cost effective, affordable, transport, ... and small enough to still leave room for future settlements.

That's how the proposed settlement sizes were derived. Real estate experts guessed at the minimum the land would bring when you could buy a ticket and get to it. Space experts guessed at what was the least that financially efficient private companies could hope to establish settlements for. The average settlement cost estimates, divided by the estimated average dollars per acre, gave the number of acres needed. Converted to square miles, that worked out to approximately 600,000 square miles on the Moon and 3,600,000 square miles on Mars (Wasser 2001).

I am curious as to who these "real estate experts" and "space experts" are. On what assumptions did they base these guesses and how valid are these assumptions?

The Space Settlement Institute believes that the most valuable resource in space is Lunar and Martian real estate (Wasser 2005-01-26).

My first reaction to this absurd claim was, "I wonder, have they taken a good look at Nevada lately?" Apparently missing my humorous intent, Wasser replied that Nevada turns out to be "an excellent analogy" and calculated a "conservative estimate" that at an average of $\$ 18,667.67$ per acre, Nevada's 70,400,000 acres of real estate are worth:

$$
\$ 18,667.67 * 70,400,000 \text { acres }=\$ 1,314,203,968,000
$$

So, at the lowest price, that's One Trillion, three hundred million dollars.

The Space Settlement Institute is proposing a land claims recognition prize of 600,000 square miles on the Moon. That's as big as Alaska - and five times as big as Nevada - but still only $4 \%$ of the Lunar surface.

So, as you say, having taken a good look at Nevada, The Space Settlement Institute believes that the most valuable resource in space is Lunar and Martian real estate (Wasser 2005-03-05).

Nevada is "an excellent analogy?" How so? Nevada may be in the middle of nowhere, but at least it has breathable air. The Moon and Mars are well beyond the outskirts of nowhere, and neither has breathable air. I (and millions of other Californians) can get to Nevada in four hours on a tank of gasoline. I (or, more likely, my ashes) can get to the Moon or Mars in 15 years on a $\$ 50$ billion investment in developing flight hardware, software, and operations training. As for water and vegetation, Nevada is a veritable rain forest by comparison. In terms of proximity and accessibility of resources, Nevada is orders of magnitude more valuable than the Moon or Mars. To paraphrase General William Tecumseh Sherman, if I owned both Nevada and Mars, I would live in Nevada and rent out Mars.

Another calculation Wasser ran was based on Dennis Hope's Lunar Embassy scheme:

Since 1980 a man by the name of Dennis Hope has made a small fortune selling Lunar "deeds". He simply announced that he had claimed the Moon, set up his own "Lunar Embassy", and has sold unrecognized Lunar land "deeds" for $\$ 19.99$ an acre (\$22.49 if you want your name printed on the deed).

Currently, Dennis Hope's website lunarembassy.com has sold over 2,300,000 Lunar "properties" to people in 165 countries. So Hope has proven beyond doubt that real deeds, recognized by the US and actually accessible by a thenexisting commercial space line - would certainly be worth no less than $\$ 19.99$ /acre. 19.99 times 9,383,748,198 acres $=$ $\$ 187,581,126,478$. That is nearly $\$ 190$ billion dollars - absolute minimum worst-case value (Wasser 2005-03-05).

For Wasser to invoke Hope hardly enhances the credibility of either of them. In any case, it takes more than simple arithmetic to understand the mathematics of economics. If this were all there was to it, who would ever have cared about John Forbes Nash's "beautiful mind?" Wasser neglects basic economic principles such as market size and price elasticities/inelasticities. The fact that Dennis Hope can take \$20 each from thousands of people cannot be scaled linearly to infer that there are the billions of buyers who would be required to finance Wasser's grandiose schemes. It is entirely invalid to extrapolate even a couple of orders of magnitude beyond the referenced data set. Also, a given person may buy an acre of lunar "property" and show the deed around to his friends as a novelty, but 


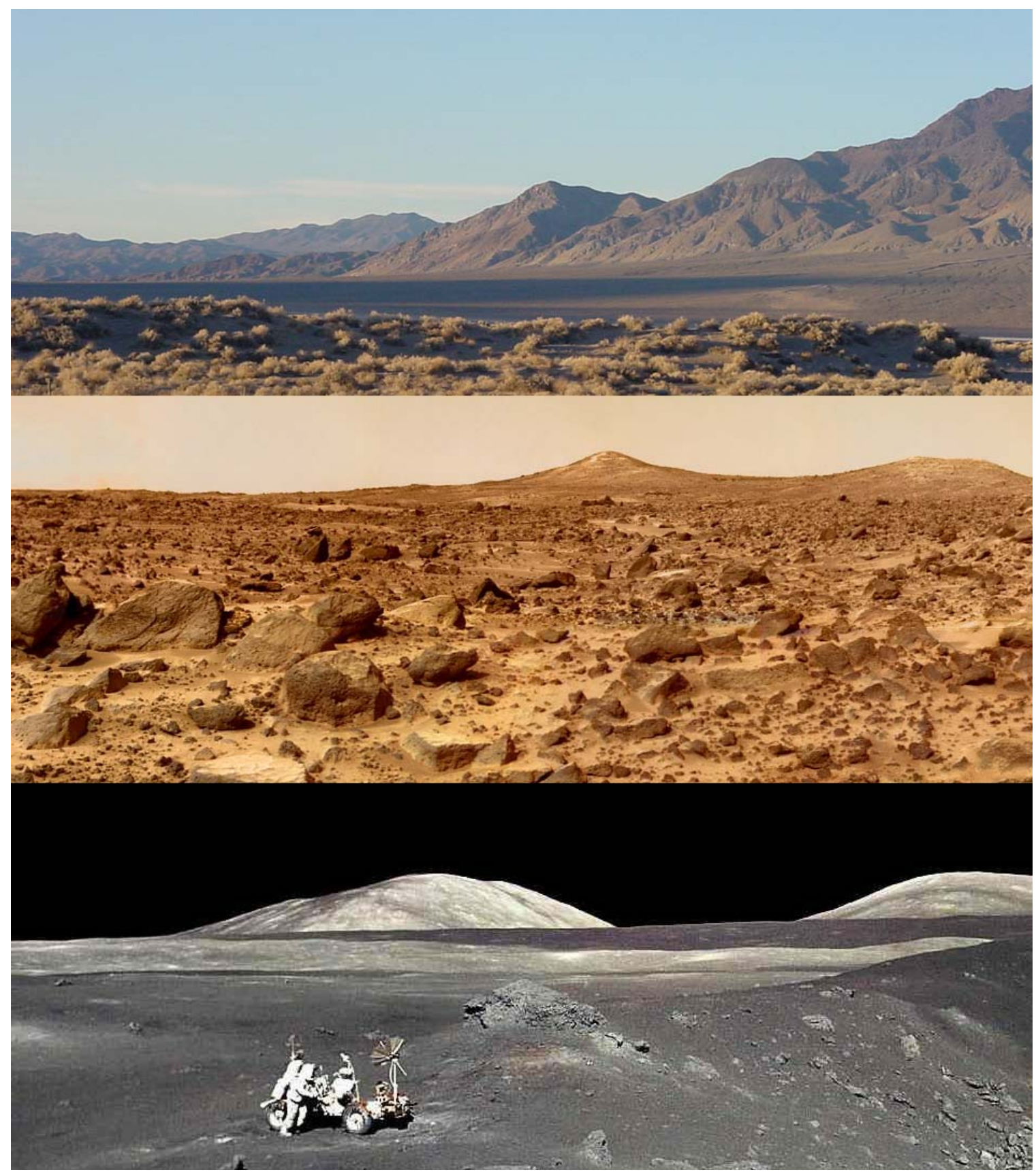

Figure 2. Real Estate in Nevada and on Mars and the Moon

Sources: elams.org and NASA

is he going to buy a thousand acres and thereby impress his friends with what an idiot he is? The per-acre price of a thousand-acre lot just isn't the same as the price of a one-acre lot.

My estimate of Wasser's business model is as follows. Dennis Hope claims that he has had "more than $3,470,072$ customers" in the 26 years he has been in business. Let us stipulate that there are 3.5 million more as-yet untapped suckers in the world (or will be, according to Barnum's Law, ${ }^{5}$ by the time the first privately-financed lunar settlement is established). Let us also stipulate, for the moment, that Hope's going price of $\$ 20$ per acre holds, despite the fact that this private entity, which has been cash-flow negative until this point and is desperate for

\footnotetext{
5 “There's a sucker born every minute."
} 
revenue, has now glutted the lunar land market with 600,000 square miles of property for sale, rather than distributing the sales over a 26 -year period. The company cannot afford to wait 26 years; it needs the money now! Since there are 640 acres in a square mile, this amounts to 384 million acres. This means that these 3.5 million potential buyers would have to buy an average of not just one acre, but 110 acres, for an average price of $\$ 2,200$ per buyer.

The problem is that the market history is of 3.5 million customers over a 26-year period at a price of only $\$ 20$. How credible is it that there will be a market of 3.5 million customers at a price of $\$ 2,200$ over a period of, let us say, a year or two? Not very. Prices will be elastic, since no one on Earth needs to buy land on the Moon; this is an optional purchase. There will be substantially fewer than 3.5 million buyers, and prices will collapse.

So, let us come up with a more credible model, and speculate that there might be 350,000 people who would be willing to spend $\$ 220$ on something that almost none of them will ever be able to see or touch, raising a grand total of $\$ 76$ million. That might buy a second-hand space suit for someone who got to be an astronaut when he or she grew up. ${ }^{6}$

There is more to consider on the subject of the value of scarcity. Regarding his continent-sized land grants, Wasser points out:

Fortunately, that is quite small enough to still leave plenty of room for subsequent settlements, since it is only around $4 \%$ of the Moon, $6.5 \%$ of Mars (Wasser 2001).

How true. The surface area of the Moon is equal to all of South America, and the surface area of Mars is equal to all of the land area of Earth. This is hardly what one would call a scarce resource. So, what tangible difference is there between the unimproved land inside Wasser's property fence and the unimproved land outside it? I am reminded of the scene in Monty Python's Life of Brian, in which an entrepreneur sells rocks to the righteous on the road to stoning a blasphemer.

Of course, the establishment of their space transport service, which enabled the consortium to win the land grant in the first place, will dramatically increase the value of their land over what it is worth today, when it is inaccessible. As with the land grants that paid for building America's trans-continental railroads, vast wealth would be created (out of thin vacuum, so to speak) by giving formerly worthless land real value and an owner (Wasser 1997).

There are several inaccuracies in this paragraph. First of all, wealth is never created "out of thin vacuum." Wealth is created from productive activity involving land, capital, and labor. In contrast, Wasser uses language that conjures visions of Ponzi schemes, where money from later investors is used to pay off earlier investors, but all such schemes ultimately collapse. The early investors make out like bandits because they have robbed the later investors, who end up with nothing (SEC 2001, 2004).

Also, it very plainly would have been impossible for "land grants [to have] paid for building America's transcontinental railroads." If the land over which the railroads were about to be built was worthless, it could not have been a source of capital for building the railroads. Wasser has confused cause and effect; the land began to acquire some value once the infrastructure was in place, once value had been added to the land by the productive application of labor and capital. Given the level of technology, it obviously took a tremendous amount of human labor to build the transcontinental railroads; it also took a great deal of capital.

In addition to the grant of lands and right of way, Government agreed to issue its thirty year six per cent. Bonds in aid of the work, graduated as follows: For the plains portion of the road, $\$ 16,000$ per mile; for the next most difficult portion, $\$ 32,000$ per mile; for the mountainous portion, $\$ 48,000$ per mile.

The Union Pacific Railroad Co. built 525 78/100 miles, for which they received $\$ 16,000$ per mile; 363 602/1000 miles at $\$ 32,000$ per mile; 150 miles at $\$ 48,000$ per mile, making a total of $\$ 27,236,512$.

The Central Pacific Railroad Co. built $718 / 100$ miles at $\$ 16,000$ per mile; 580 32/100 miles at $\$ 32,000$ per mile; 150 miles at $\$ 48,000$ per mile, making a total of $\$ 25,885,120$.

The total subsidies for both roads amount to $\$ 53,121,632$. Government also guaranteed the interest on the Companies' first mortgage bonds to an equal amount (Crofutt 1871, 15).

$\$ 53,121,632$ in 1865 dollars equates to more than a billion in 2005 dollars... to build a railroad that private investors, not the taxpayers, own. Far greater subsidies and loan guarantees will be necessary to establish regular transportation service to and a settlement on the Moon or Mars. These projects cannot possibly be financed with grants of as-yet valueless land, any more than the transcontinental railroads were this way. These unimproved (indeed, presently unimprovable due to their inaccessibility) land holdings will secure no present loans, will purchase no present material, and will pay no present wages, whatever their "guessed" future value may be. This would be true even if recognition were given to the land claim on the day that the project began, rather than the land claim being contingent on the success of the project. It is important to remember that, pursuant to Section 4 , paragraph 1 of the SSPA, US courts would only "give recognition, certification, and full legal support to land

\footnotetext{
${ }^{6}$ A new extravehicular suit costs between $\$ 300$ million and $\$ 700$ million (Harris 2001). Oxygen sold separately.
} 
ownership claims based on use and occupation" once a private entity has "established a permanently inhabited settlement on the Moon, Mars, or an asteroid, with regular transportation between the settlement." Unless and until these conditions were fulfilled, the private entity would own nothing at all.

Once the space transportation system and lunar base were certified, the private consortium would be free to immediately mortgage or sell, back here at home, some of their lunar land deeds to recoup their investment and make a profit (Wasser 2004a).

On the other hand, one might pick up one of the many rocks on the side of the road that are free for the taking, for the condemned blasphemer cannot not tell the impact of a free rock from a purchased one.

\section{Conclusion}

The Space Settlement Initiative is so flawed in its historical analysis and justification, in its theoretical and philosophical underpinnings, in its legal grounding, and in its financial strategy, that the practical effect is to solicit money and/or effort from people for a political project that is exceedingly unlikely to succeed.

\section{References}

Crofutt, George A. 1871. “Crofutt's Trans-Continental Tourist's Guide." Internet. Available from http://libr.unl.edu:2000/westward_through_nebraska/CG1871w.3.html; accessed 18 February 2006.

Csabafi, Imre. 1965. "The UN General Assembly Resolutions on Outer Space as Sources of Space Law." Proceedings, 8th Colloquium on the Law of Outer Space, 337-361. American Institute of Aeronautics and Astronautics.

Danilenko, Gennady M. 1989. "Outer Space and the Multilateral Treaty-Making Process." Berkeley Technology Law Journal, Vol. 4, No. 2. Internet. Available from http://www.law.berkeley.edu/journals/btlj/articles/vol4/Danilenko/HTML/ text.html; accessed 19 March 2005.

Jobes, Douglas O. and Alan B. Wasser. 2004. "Land Claim Recognition (LCR) Analysis: Leveraging the Inherent Value of Lunar Land for Billions in Private Sector Investment." Space Settlement Institute. Internet. Available from http://www.spacesettlement-institute.org/Articles/LCRbrieftext.htm; accessed 16 March 2005.

Kennedy, John F. 1961. "Inaugural Address.” 20 January. Internet. Available from http://www.jfklibrary.org/j012061.htm; accessed 3 January 2006.

Locke, John 1689. The True Original, Extent, and End of Civil-Government. Internet. Available from http://www.constitution.org/j1/2ndtr00.htm; accessed 26 December 2005.

Peterson, M. J. 1997. “The Use of Analogies in Developing Outer Space Law.” International Organization, 51, $2,245-74$.

Rousseau, Jean-Jacques. 1762 The Social Contract. Translated by G. D. H. Cole. Internet. Available from http://www.constitution.org/jjr/socon.htm; accessed 28 December 2005.

Silber, Kenneth. 1998. "A Little Bit of Heaven: Space-Based Commercial Property Development." Reason, November. Internet. Available from http://www.findarticles.com/p/articles/mi_m1568/is_n6_v30/ai_21231184; accessed 19 March 2005.

Space Daily. 1988. "National Space Society Airs '67 Outer Space Treaty Reservations.” 5 February. Internet. Available from http://www.space-settlement-institute.org/Articles/research_library/TreatyReservations.pdf; accessed 24 March 2005.

Space Daily. 2003. "Moon Society and Artemis Society Endorse Space Settlement Initiative." 30 April. Internet. Available from http://www.spacedaily.com/news/mars-base-03b.html; accessed 17 March 2005.

Tennen, Leslie I. 2003. "Commentary on Emerging System of Property Rights in Outer Space." United Nations - Republic of Korea Workshop on Space Law. Internet. Available from http://www.oosa.unvienna.org/SAP/act2003/repkorea/presentations/ specialist/ost2/tennen.doc; accessed 19 March 2005.

Treverton, Gregory F. and Pamela Varle. 1992. "The United States and South Africa: The 1985 Sanctions Debate.” Institute for the Study of Diplomacy, School of Foreign Service, Georgetown University.

United Nations. 1967. "Treaty on Principles Governing the Activities of States in the Exploration of Outer Space, Including the Moon and other Celestial Bodies." 610 U.N.T.S. 205. Internet. Available from http://www.iasl.mcgill.ca/spacelaw/ outerspace.html; accessed 17 September 2004.

United Nations. 1979. "Agreement Governing the Activities of States on the Moon and Other Celestial Bodies." 1363 U.N.T.S. 3. Internet. Available from http://www.iasl.mcgill.ca/spacelaw/moon.html; accessed 17 September 2004.

United Nations Committee on the Peaceful Uses of Outer Space. 1962. U.N. Doc. A/AC.105/L.2.

United States Securities and Exchange Commission. 2001. “.”Internet. Available from http://www.sec.gov/answers/ ponzi.htm; accessed 18 February 2006.

United States Securities and Exchange Commission. 2004. “.”Internet. Available from http://www.sec.gov/answers/ pyramid.htm; accessed 18 February 2006.

United States Senate. 1980. "The Moon Treaty." Hearings Before the Subcommittee on Science, Technology, and Space of the Committee on Commerce, Science, and Transportation. 96th Congress, 2nd Session.

University of Bristol Department of Philosophy. 2005. "John Locke (1632-1704): Property rights and their limits?" Internet. Available from http://www.bris.ac.uk/philosophy/current/undergrad/unitdesc/yr1/0506/soccontracttheory/lecture4.html; accessed 26 December 2005. 
Wasser, Alan B. 1988. "National Space Society Airs '67 Outer Space Treaty Reservations.” Space Daily, 5 February. Internet. Available from http://www.space-settlement-institute.org/Articles/archive/TreatyReservations.pdf; accessed 25 March 2005.

Wasser, Alan. 1997. "How to Restart a Space Race to the Moon and Mars.” Moon Miners' Manifesto, \#103, March. Internet. Available from http://www.asi.org/adb/06/09/03/02/103/space-race.html; accessed 19 March 2005.

Wasser, Alan. 2001. "The Space Settlement Initiative." Space Future, 9 October. Internet. Available from http://www.spacefuture.com/archive/the_space_settlement_initiative.shtml; accessed 26 December 2005.

Wasser, Alan B. 2004. "The Space Settlement Initiative." Space Settlement Institute. Internet. Available from http://www.spacesettlement.org/; accessed 19 March 2005.

Wasser, Alan. 2004a. "The Space Settlement Prize." Space Review, 18 October. Internet. Available from http://www.thespacereview.com/article/249/1; accessed 26 December 2005.

Wasser, Alan. 2005. Email, 5 March.

White, Wayne N. 1998. "Real Property Rights in Outer Space." Proceedings, 40th Colloquium on the Law of Outer Space, 370. American Institute of Aeronautics and Astronautics. Internet. Available from http://www.spacefuture.com/ archive/real_property_rights_in_outer_space.shtml; accessed 19 March 2005.

Wired.com. 2004. "What Rich Guys Buy." Internet. Available from http://www.wired.com/wired/archive/12.07/ start.html?pg=9; accessed 18 February 2006. 